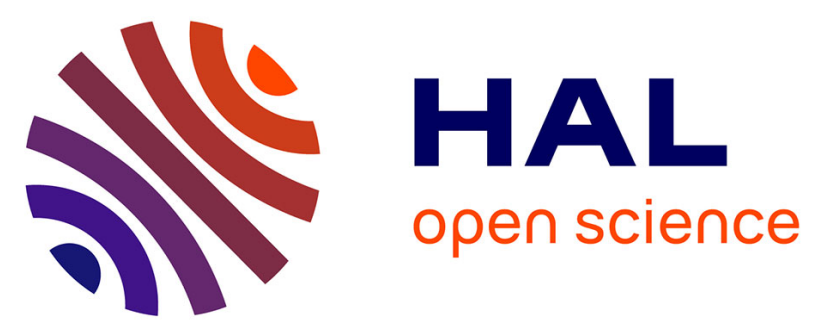

\title{
Amorphous Surface Layer versus Transient Amorphous Precursor Phase in Bone - A Case Study Investigated by Solid-state NMR Spectroscopy
}

Stanislas von Euw, Widad Ajili, Tsou-Hsi-Camille Chan-Chang, Annette Delices, Guillaume Laurent, Florence Babonneau, Nadine Nassif, Thierry Azaïs

\section{To cite this version:}

Stanislas von Euw, Widad Ajili, Tsou-Hsi-Camille Chan-Chang, Annette Delices, Guillaume Laurent, et al.. Amorphous Surface Layer versus Transient Amorphous Precursor Phase in Bone - A Case Study Investigated by Solid-state NMR Spectroscopy. Acta Biomaterialia, 2017, 59, pp.351-360. 10.1016/j.actbio.2017.06.040 . hal-01559945

\section{HAL Id: hal-01559945 \\ https://hal.sorbonne-universite.fr/hal-01559945}

Submitted on 11 Jul 2017

HAL is a multi-disciplinary open access archive for the deposit and dissemination of scientific research documents, whether they are published or not. The documents may come from teaching and research institutions in France or abroad, or from public or private research centers.
L'archive ouverte pluridisciplinaire HAL, est destinée au dépôt et à la diffusion de documents scientifiques de niveau recherche, publiés ou non, émanant des établissements d'enseignement et de recherche français ou étrangers, des laboratoires publics ou privés. 


\title{
Amorphous Surface Layer versus Transient Amorphous Precursor Phase in Bone - A Case Study Investigated by Solid-state NMR Spectroscopy
}

\author{
Stanislas Von Euw, ${ }^{\text {a }}$ Widad Ajili, ${ }^{\mathrm{a}}$ Tsou-Hsi-Camille Chan-Chang, ${ }^{\mathrm{a}}$ Annette Delices, ${ }^{\mathrm{a}}$ Guillaume \\ Laurent, ${ }^{a}$ Florence Babonneau, ${ }^{\mathrm{a}}$ Nadine Nassif ${ }^{\mathrm{a}}$ and Thierry Azaiis ${ }^{\mathrm{a}}$ \\ ${ }^{a}$ Sorbonne Universités, UPMC Univ Paris 06, CNRS, Collège de France, Laboratoire de Chimie \\ de la Matière Condensée de Paris (LCMCP), 4 place Jussieu, F-75005, Paris, France.
}

*corresponding author: thierry.azais@upmc.fr; +33144275675

\begin{abstract}
The presence of an amorphous surface layer that coats a crystalline core has been evidenced for many biominerals, including bone mineral. In parallel, transient amorphous precursor phases have been proposed in various biomineralization processes, including bone biomineralization. Here we propose a methodology to investigate the origin of these amorphous environments taking the bone tissue as a key example. This study relies on the investigation of a bone tissue sample and its comparison with synthetic calcium phosphate samples, including a stoichiometric apatite, an amorphous calcium phosphate sample, and two different biomimetic apatites.

To reveal if the amorphous environments in bone originate from an amorphous surface layer or a transient amorphous precursor phase, a combined solid-state nuclear magnetic resonance (NMR) experiment has been used. The latter consists of a double cross polarization ${ }^{1} \mathrm{H} \rightarrow{ }^{31} \mathrm{P} \rightarrow{ }^{1} \mathrm{H}$ pulse sequence followed by a ${ }^{1} \mathrm{H}$ magnetization exchange pulse sequence. The presence of an amorphous surface layer has been investigated through the study of the biomimetic apatites; while the presence of a transient amorphous precursor phase in the form of amorphous calcium phosphate particles has been mimicked with the help of a physical mixture of stoichiometric apatite and amorphous calcium phosphate. The NMR results show that the amorphous and the crystalline environments detected in our bone tissue sample belong to the same particle. The presence of an amorphous surface layer that coats the apatitic core of bone apatite particles has been unambiguously confirmed, and it is certain that this amorphous surface layer has strong implication on bone tissue biogenesis and regeneration.
\end{abstract}

Keywords: bone mineral; bone apatite; biomimetic apatite; amorphous calcium phosphate, stoichiometric apatite; amorphous surface layer, solid-sate NMR; biomineralization 


\section{Introduction}

The presence of an amorphous surface layer that coats a crystalline nanoparticle core has been proposed both in calcium phosphate and calcium carbonate biominerals, including the apatite nanoparticles constituting the bone mineral [1] and the aragonite particles constituting the nacre of the molluscan shells [2], respectively. In parallel, both transient amorphous calcium phosphate [3,4] and transient amorphous calcium carbonate [5-7] phases have been observed at the early stages of biomineralization in bone, enamel, the spines of sea urchin and in nacre. Here we propose a methodology to investigate the origin of these amorphous environments in the case of a bone tissue sample originating from a two-year-old sheep and through its comparison with synthetic calcium phosphate samples.

While there is no doubt that the mature bone mineral is made of crystalline calcium phosphate in the form of apatite [8], the question regarding the presence or not of amorphous calcium phosphate (ACP) in bone mineral has been deeply investigated over the past couple of decades [9], and is still widely debated nowadays [10-12]. The bone apatite particles are in the form of nanosized platelets with irregular shapes and dimensions $[13,14]$, i.e., $\sim 1-4 \mathrm{~nm}$ of thickness, $\sim 8-15 \mathrm{~nm}$ of width and $\sim 20-35 \mathrm{~nm}$ of length. This bone apatite is described as a calcium-deficient and hydroxyl-deficient carbonated hydroxyapatite [15-17], with a chemical composition that varies greatly with respect to the so-called stoichiometric hydroxyapatite $\left(\mathrm{Ca}_{10}\left(\mathrm{PO}_{4}\right)_{6}(\mathrm{OH})_{2}\right)$ due to numerous ionic substitutions - and, in particular, carbonate ions present from $\sim 4$ up to $\sim 9 \% \mathrm{w} / \mathrm{w}$. Moreover, spectroscopic investigations, microscopy observations, and X-ray analyzes, have provided strong evidence of the presence of non-apatitic environments closely related to ACP in bone mineral. Studies involving newly formed, intermediate, and mature bone mineral, as well as synthetic biomimetic apatites (i.e., synthetic 
carbonated nanocrystalline hydroxyapatites) have been reported - and it was proposed that these ACP environments might have two origins: (i) an ACP-like surface layer that coats the bone apatite particles; and/or (ii) a transient ACP phase present at the early stages of bone mineralization. Indeed, the existing model that describes the bone apatite and biomimetic apatite particles predict a core/shell structure, with the ACP-like environments in the form of a very thin mineral surface layer that coats the apatitic environments localized into the bulk of the particle. The accuracy of this model is still debated because the exact origin of the ACP environments is still not clear: transient phase $v s$ surface layer, either one or the other, or both of the two forms present at the same time in a bone sample.

Particular surface properties of bone mineral were first reported in the fifties from ionic exchange experiments, which would involve "a surface hydration shell containing non-specific boundary anions in rapid equilibrium with the surrounding medium" [18]. The first electron microscopy studies on the early stages of bone mineral deposition suggested that "the crystals are not only smaller, but that some of the observed inorganic components in newly formed bone may not be in a crystalline form" [19]. The presence of ACP as an intermediate in the precipitation of apatite was confirmed in vitro in the mid-sixties with the help of X-ray diffraction [20]. Soon after this, based on X-ray diffraction analysis by measuring the background intensity, ACP environments were both detected and quantified in bone mineral [21-23]. The first spectroscopic evidence of the presence of ACP environments in bone mineral was reported at that time using infrared spectroscopy by analyzing the $v_{4}$ vibration mode of orthophosphate ions [24]. However, in the early eighties, with the help of both X-ray diffraction and X-ray radial distribution measurements, M. Glimcher and his colleagues undertook an extensive study that led to the conclusion that the presence of ACP in bone mineral has to be reconsidered [25-27]. Indeed, 
they concluded that the ACP environments in newly formed bone mineral, previously reported by A. Posner and his colleagues, were actually only "poorly crystalline hydroxyapatite" environments [26]. Other spectroscopic evidences of the presence of ACP or "poorly crystalline hydroxyapatite" environments in bone mineral were reported in 1994 using solid-state nuclear magnetic resonance (NMR) spectroscopy with the help of the $\left\{{ }^{1} \mathrm{H}\right\}^{31} \mathrm{P}$ cross polarization (CP) experiment $[28,29]$. These ACP-like environments have been described as "a unique protonated phosphate group in bone mineral not present in synthetic calcium phosphates" [29], as well as "a second phosphorus site interacting with structural water molecules”[28]. In parallel, several studies have reported the presence of related ACP-like environments in various biomimetic apatites, using infrared spectroscopy [30-32], X-ray radial distribution analysis [33], X-ray absorption spectroscopy [34], and solid-state NMR spectroscopy [35-37]. Furthermore, ionic exchange properties involving the presence of loosely bound ions at the particle's surface has also been reported for biomimetic apatites [38-40]. These two concepts involving surface properties and ACP-like environments have therefore gradually merged together, and the models of the bone and biomimetic apatite particles have emerged [1,41-45]: a nanosized platelet constituted by a crystalline core in the form of hydroxyapatite coated by an ACP-like surface layer. Furthermore, a similar core/shell model has also been proposed for the elongated dentin apatite particles [46-48]. High-resolution transmission electron microscopy (HR-TEM) observations have strengthened the accuracy of this model. Indeed, the presence of an amorphous surface layer ( 1-2 nm thick) was sometimes reported from synthetic apatite samples $[1,49,50]$. However, such observations are debatable because a degradation of the particles might happen following the electron beam irradiation. 
In parallel, the presence of ACP environments in bone mineral in the form of a transient amorphous precursor phase is worth considering. Indeed, ACP particles have been observed at the early stages of the apatite crystallization process in vitro (with or without the presence of organic additives) [20,51-59] and in vivo [3,4,60-62]. In particular, in the case of the growing fin bony rays of the zebrafish, recent studies have shown that the new mineral is delivered and deposited as packages of ACP nano-spheres, which transform into platelets of crystalline apatite within the collagen matrix [63].

The aim of this study is to assess the two scenarios likely to happen in bone mineral: (1) an ACP-like surface layer which coats an apatitic crystalline nanoparticle core; and/or (2) the presence of ACP particles and apatite crystals apart. For this purpose, a combined solid-state NMR experiment has been applied to a bone tissue sample originating from a two-year-old sheep and to various well-characterized and carefully chosen synthetic calcium phosphate samples. This includes: (i) two biomimetic apatites samples composed by the addition of apatitic and ACP-like environments in the same particle; and (ii) a physical mixture of a stoichiometric apatite sample (only composed of apatitic environments) and an amorphous calcium phosphate sample (only composed of amorphous environments). The two biomimetic apatites have been used to mimic the scenario (1), while the physical mixture of the stoichiometric apatite and the amorphous calcium phosphate samples has been used to mimic the scenario (2). The solid-state NMR experiment consists of $(i)$ a double cross polarization $(\mathrm{CP}){ }^{1} \mathrm{H} \rightarrow{ }^{31} \mathrm{P} \rightarrow{ }^{1} \mathrm{H}$ pulse sequence [64], in order to edit the ${ }^{1} \mathrm{H}$ resonances related to calcium phosphate environments, followed by (ii) a ${ }^{1} \mathrm{H}$ magnetization exchange pulse sequence based on the ${ }^{1} \mathrm{H}$ spin diffusion process (EXchange SpectroscopY, EXSY) in order to probe the continuity between the apatitic and the amorphous environments. 


\section{Materials and methods}

\subsection{Samples preparation}

The stoichiometric hydroxyapatite, HA, was obtained following the synthesis described by Takemoto et al. [65]. The double-distilled water used in the different steps of the synthesis has been boiled for 2 hours, and then cooled under $\mathrm{N}_{2}$ bubbling to remove the dissolved $\mathrm{CO}_{2}$. Briefly, $100 \mathrm{~mL}$ of a $0.3 \mathrm{M}\left(\mathrm{NH}_{4}\right)_{2} \mathrm{HPO}_{4}$ aqueous solution (pH fixed at 10 with the help of a 28 $\% \mathrm{w} / \mathrm{w}$ ammonia aqueous solution) was added to $105 \mathrm{~mL}$ of a $0.5 \mathrm{M} \mathrm{Ca}\left(\mathrm{NO}_{3}\right)_{2} .4 \mathrm{H}_{2} \mathrm{O}$ aqueous solution at room temperature under an $\mathrm{N}_{2}$ atmosphere and rigorous stirring at a feeding rate of 3 $\mathrm{mL} / \mathrm{min}$ controlled by an automatic titrator (Titrando 808, Metrohm). Once the addition was completed, the mixture was kept under stirring for 24 hours. The solid obtained was centrifuged (6000 rpm, $10 \mathrm{~min}$ ) and washed 3 times with double-distilled water before being dried at $105^{\circ} \mathrm{C}$ for 3 days, and then heated at $400^{\circ} \mathrm{C}$ for 3 hours before characterization.

The amorphous calcium phosphate sample, ACP, was obtained according to the Heughebaert method [66]. $46.3 \mathrm{~g}$ of $\mathrm{Ca}\left(\mathrm{NO}_{3}\right)_{2} \cdot 4 \mathrm{H}_{2} \mathrm{O}$ were dissolved in $0.55 \mathrm{~L}$ aqueous solution of ammonia of approximately $1.1 \mathrm{M}$, and $27.2 \mathrm{~g}$ of $\left(\mathrm{NH}_{4}\right)_{2} \mathrm{HPO}_{4}$ were dissolved in $1.3 \mathrm{~L}$ aqueous solution of ammonia of approximately $0.5 \mathrm{M}$. The precipitate was formed following the rapid addition of the calcium solution into the orthophosphate solution. The precipitate was filtered through a Büchner funnel, washed with an aqueous solution of ammonia of approximately 0.08 $\mathrm{M}$, frozen in liquid $\mathrm{N}_{2}$, lyophilized for a period of 72 hours, and finally stored at $-20^{\circ} \mathrm{C}$.

The physical mixture of the stoichiometric apatite sample and the amorphous calcium phosphate sample, HA/ACP mixture, was made by mixing the same mass of HA and ACP, giving a 50:50 w/w mix ratio. The powders were placed in a mortar and mixed for $10 \mathrm{~min}$. Then 
the mixture were introduced in a vortex mixer and mixed for $10 \mathrm{~min}$ in order to obtain a mixture as homogeneous as possible.

The first biomimetic apatite, CHA (i.e., a carbonated hydroxyapatite), was obtained at ambient temperature by an ammonia gas diffusion method described by Nassif et al. [67] (referred as HA-2 in the referenced article). An aqueous reaction solution containing $110 \mathrm{mM}$ $\mathrm{CaCl}_{2} \cdot 2 \mathrm{H}_{2} \mathrm{O}, 33 \mathrm{mM} \mathrm{NaH} \mathrm{PO}_{4} \cdot \mathrm{H}_{2} \mathrm{O}$ and $33 \mathrm{mM} \mathrm{NaHCO} 3$ was prepared. The $\mathrm{pH}$ of this reaction solution was adjusted to 2.2 with a $1 \mathrm{M} \mathrm{HCl}$ aqueous solution added dropwise. Two flasks (35 $\mathrm{mL}, 50 \mathrm{~mm}$ height $)$ containing this reaction solution $(20 \mathrm{~mL}$ each) and covered by perforated Parafilm (to slow down the ammonia gas diffusion) were placed into a closed chamber (i.e., a 1 L beaker) - and an ammonia aqueous solution $(28 \% \mathrm{w} / \mathrm{w}, 8 \mathrm{~mL})$ was also placed in the chamber. The $\mathrm{pH}$ of the reaction solution gradually increases following the solubilization of the ammonia gas leading to the precipitation of the mineral. After 6 days, the precipitate was centrifuged (6000 rpm, $10 \mathrm{~min}$ ) and washed 3 times with double-distilled water, and then dried at $37^{\circ} \mathrm{C}$ for 7 days before characterization.

The second biomimetic apatite, CHA-SBF, (i.e., a hydroxyl-deficient carbonated, and potentially substituted with various ionic species, hydroxyapatite), was precipitated from a 1.5 simulated body fluid solution (i.e., 1.5 SBF). The latter is a solution having 1.5 times higher ion concentrations than that of a simulated body fluid (SBF). This 1.5 SBF solution was prepared according to the procedure described by Rhee \& Tanaka [68], by dissolving the following salts at $37^{\circ} \mathrm{C}$, in the order listed: $\mathrm{NaCl}(11.99 \mathrm{~g}), \mathrm{NaHCO}_{3}(0.529 \mathrm{~g}), \mathrm{KCl}(0.335 \mathrm{~g}), \mathrm{K}_{2} \mathrm{HPO}_{4} .3 \mathrm{H}_{2} \mathrm{O}$ (0.342 g), $\mathrm{MgCl}_{2} \cdot 6 \mathrm{H}_{2} \mathrm{O}(0.457 \mathrm{~g}), \mathrm{CaCl}_{2}(0.416 \mathrm{~g}), \mathrm{Na}_{2} \mathrm{SO}_{4}(0.107 \mathrm{~g})$ in $1 \mathrm{~L}$ of double-distilled water buffered at $\mathrm{pH} 7.4$ with $1.2 \mathrm{~g}$ of tris(hydroxymethyl)aminomethane and a few drops of a 1 $\mathrm{M} \mathrm{HCl}$ aqueous solution. This $1.5 \mathrm{SBF}$ solution was first frozen at $-20^{\circ} \mathrm{C}$ for $1 \mathrm{night}$, and then 
left at $5^{\circ} \mathrm{C}$ for 2 days. This procedure yielded a precipitate that was centrifuged $(6000 \mathrm{rpm}, 10$ min) and washed 3 times with double-distilled water, and then dried at $37^{\circ} \mathrm{C}$ for 7 days before characterization.

The bone tissue sample originated from a two-year-old healthy French sheep. This sample has been extracted from the distal femoral metaphysis, and dried for 24 hours under sterile conditions (i.e., under laminar flow hood at ambient temperature). The study was reviewed and approved by the IMM Recherche's Institutional Animal Care and Use committee (IACUC) prior to starting. The animal research center (IMMRecherche) received an approval ( $\left.\mathrm{n}^{\circ} 75-14-01\right)$ on September 08th, 2008 for a period of 5 years by the "Sous-Direction de la protection Sanitaire" of the French Authorities.

\subsection{Samples characterization}

\subsubsection{General characterization}

Powder X-ray diffraction (XRD) patterns of all samples were recorded using a Bruker D8 $\mathrm{X}$-ray diffractometer operating in the reflection mode at $\mathrm{CuK \alpha}$ radiation, with $40 \mathrm{kV}$ beam voltage and $40 \mathrm{~mA}$ beam current. The data were collected in the $10-60^{\circ}$ range $(2 \theta)$ with steps of $0.019^{\circ}$ and a counting time of $2 \mathrm{~s}$.

Fourier-transform infrared spectroscopy FT-IR experiments were performed on a Nicolet Magna FT-IR spectrometer in the range of $650-4000 \mathrm{~cm}^{-1}$ at a resolution of $4 \mathrm{~cm}^{-1}$.

Thermogravimetric analysis (TGA) experiments were performed on a thermomicrobalance instrument (NETZSCH STA 409PC). The measurements were performed from room temperature to $1000^{\circ} \mathrm{C}$ in air atmosphere with a heating rate of $5^{\circ} \mathrm{C} / \mathrm{min}$.

For transmission electron microscopy (TEM) observations, the different powders were dispersed in anhydrous ethanol. A few drops of the resulting dispersions were deposited on a 
carbon-coated copper grid. After solvent evaporation, TEM investigations were performed with a FEI TECMAI G2 Spirit Twin electron microscope operating at $120 \mathrm{kV}$.

\subsubsection{Solid-state NMR}

The ${ }^{1} \mathrm{H}$ and ${ }^{31} \mathrm{P}$ solid-state nuclear magnetic resonance (NMR) experiments were conducted on an Avance-III 300 Bruker spectrometer. Samples were packed into 4 mm (O.D.) zirconia rotors, and experiment were conducted using magic angle spinning (MAS). The frequency $\left(\nu_{\text {MAS }}\right)$ was set at $14 \mathrm{kHz}$ using a Bruker $4 \mathrm{BL} \mathrm{CP} / \mathrm{MAS}{ }^{1} \mathrm{H} / \mathrm{BB}$ probe. ${ }^{1} \mathrm{H}$ recycle delays were set to $2 \mathrm{~s}$ for bone, ACP and biomimetic apatites, and $30 \mathrm{~s}$ for stoichiometric apatite to ensure the full relaxation of the samples. ${ }^{31} \mathrm{P}$ recycle delays were set to $200 \mathrm{~s}$ for all samples to ensure the full relaxation. Two-dimensional $\left\{{ }^{1} \mathrm{H}\right\}{ }^{31} \mathrm{P}$ HetCor NMR spectra were recorded with 40 to 80 scans each 100 to $200 t_{1}$ increments depending on the samples. The contact time $\left(t_{C P}\right)$ was set to 1,2 or $3 \mathrm{~ms}$. The ${ }^{1} \mathrm{H} \rightarrow{ }^{31} \mathrm{P} \rightarrow{ }^{1} \mathrm{H}$ Double CP MAS NMR spectra were recorded with a first $\mathrm{t}_{\mathrm{CP}} 1=1 \mathrm{~ms}$ and a second $\mathrm{t}_{\mathrm{CP}} 2=850 \mu \mathrm{s}$ in order to maximize the $5-15 \mathrm{ppm}$ resonances of the ${ }^{1} \mathrm{H}$ spectra compared to the hydroxyls resonance at $0 \mathrm{ppm}$. After the first $\mathrm{CP}$ transfer (during $\left.\mathrm{t}_{\mathrm{CP}} 1\right)$, the ${ }^{31} \mathrm{P}$ magnetization is flipped back along the $\mathrm{z}$-axis direction through a $90^{\circ}$ pulse. The ${ }^{1} \mathrm{H}$ residual signal is then eliminated by two low power purge pulses that are phase shifted by $90^{\circ}$ from each other at $v_{\mathrm{RF}}=v_{\mathrm{MAS}} / 2$ (HORROR condition) [69]. The length of each purge pulse is $10 \mathrm{~ms}$, which suppress all unwanted ${ }^{1} \mathrm{H}$ signals. Furthermore, within the model of thermal reservoirs [70], this ${ }^{1} \mathrm{H}$ saturation allows the transformation of the proton spin bath into a hot reservoir into which the ${ }^{31} \mathrm{P}$ magnetization can be back-transferred. After this saturation step, the ${ }^{31} \mathrm{P}$ magnetization is then flipped back into the transverse plane through a $90^{\circ}$ pulse and the second $\mathrm{CP}$ transfer (during $\mathrm{t}_{\mathrm{CP}} 2$ ) is applied prior to the ${ }^{1} \mathrm{H}$ acquisition. The Double CP EXSY MAS NMR experiments (Figure S1) were recorded through a first block of ${ }^{1} \mathrm{H}_{-}{ }^{31} \mathrm{P}-{ }^{1} \mathrm{H}$ Double CP 
MAS experiment $\left(\mathrm{t}_{\mathrm{CP}} 1=1 \mathrm{~ms} ; \mathrm{t}_{\mathrm{CP}} 2=850 \mu \mathrm{s}\right)$ followed by a standard EXSY experiment (mixing time $=10 \mu \mathrm{s}$ and $10 \mathrm{~ms}$ ). To ensure an efficient ${ }^{1} \mathrm{H}$ spin diffusion process, the experiments were conducted on dry samples. ${ }^{1} \mathrm{H}$ chemical shifts were referenced to TMS at $0.0 \mathrm{ppm}$, while ${ }^{31} \mathrm{P}$ chemical shifts were referenced to $\mathrm{H}_{3} \mathrm{PO}_{4}(85 \% \mathrm{w} / \mathrm{w}$ aqueous solution) at $0.0 \mathrm{ppm}$.

\section{Results and Discussion}

\subsection{Common characterization techniques}

Apatite environments are the only crystalline environments detected in the stoichiometric apatite (called HA) and in the two biomimetic apatites (called CHA and CHA-SBF) according to X-ray diffraction (XRD) observations (Fig. S2). The Bragg reflections of CHA and CHASBF are broadened compared to HA (Fig. S2). This broadening is diagnostic of a structural disorder brought by the various ionic substitution (mainly carbonates, see FT-IR spectra). The XRD pattern of the amorphous calcium phosphate sample (called ACP) does not display any Bragg reflection, confirming its amorphous nature. The FT-IR spectra of HA, CHA, CHA-SBF and ACP are combined in Figure S3. The asymmetric stretching band ( $v_{3}$ mode, from $1360 \mathrm{~cm}^{-1}$ to $\left.1580 \mathrm{~cm}^{-1}\right)$ and the out-of-plane bending band $\left(v_{2}\right.$ mode, at $\left.\sim 870 \mathrm{~cm}^{-1}\right)$ of the carbonate ions are clearly visible for CHA and CHA-SBF. This confirms the incorporation of carbonate ions within the CHA and CHA-SBF particles, and highlights their biomimetic nature. Do note that the $\mathrm{OH}$ stretching band at $3570 \mathrm{~cm}^{-1}$ (from the hydroxyl ions located within the crystalline apatitic environments, see the red asterisks) is clearly visible for $\mathbf{H A}$, less clearly visible for CHA, and unobservable both for CHA-SBF and ACP. The FT-IR spectrum of ACP displays a broad lineshape, and highlights the presence of water molecules (see the broad band spreading from $2500 \mathrm{~cm}^{-1}$ to $3700 \mathrm{~cm}^{-1}$ ) and the incorporation of carbonate ions (see the $v_{2}$ and $v_{3}$ modes at $\sim 870 \mathrm{~cm}^{-1}$ and $1360-1580 \mathrm{~cm}^{-1}$, respectively). Since the ACP sample was prepared in water, the 
presence of water molecules trapped within and in between the particles was expected [71,72]. This hydration is required to use this synthetic ACP sample as a model of the ACP-like environments found in bone mineral and biomimetic apatites. Indeed, the latter are sometimes called the "hydrated domain" [45] and they possess strong hydrophilic properties [1]. The incorporation of carbonate ions in the ACP sample is also important. Indeed, the presence of carbonate ions within the ACP-like environments of bone mineral and biomimetic apatites has been reported by ionic exchange and/or FT-IR experiments [38,40,45,73], and by ${ }^{13} \mathrm{C}$-based solid-state NMR experiments [1]. The weight percentages of carbonate ions in the carbonated samples were estimated from the weight loss of $\mathrm{CO}_{2(\mathrm{~g})}$ occurring between 600 and $1000^{\circ} \mathrm{C}$ in thermogravimetric analysis (TGA) [74]: 4.9\% for CHA; $~ 5.2 \%$ for CHA-SBF and $\sim 3.8 \%$ for ACP (Figure S4); while a range from $\sim 4$ to $\sim 9 \%$ was determined in bone mineral [75].

Regarding the weight percentages of water molecules, they were estimated from the weight loss occurring in the range of $25-400^{\circ} \mathrm{C}$ : $\sim 3.4 \%$ for $\mathbf{H A} ; \sim 7.3 \%$ for CHA; $13.0 \%$ for CHA-SBF and $\sim 17.0 \%$ for ACP (Figure S4). According to TEM observations, HA is composed of nanosized rod-like crystals with an average size of $\sim 25$ and $\sim 60 \mathrm{~nm}$ for the thickness and length, respectively (Fig. S5a). As bone mineral particles, CHA and CHA-SBF particles are in the form of nanosized platelets with irregular shapes and dimensions (Figs. S5 - b\&c). The platelets in CHA are relatively bigger compared to the platelets found in bone mineral (i.e., $\sim 2-9 \mathrm{~nm}$ of thickness, $-20-50 \mathrm{~nm}$ of width and $\sim 30-200 \mathrm{~nm}$ of length); whereas the platelets in CHA-SBF and the platelets found in bone mineral have similar sizes (i.e., $\sim 1-4 \mathrm{~nm}$ of thickness, $\sim 10-30 \mathrm{~nm}$ of width and $\sim 30-50 \mathrm{~nm}$ of length). ACP is composed of sphere-like particles with a typical diameter from 20 to $50 \mathrm{~nm}$ (Fig. S5d). It is worth mentioning that no evidence of ACP particles was reported by TEM in CHA and CHA-SBF. 


\subsection{One-dimensional solid-state NMR}

Some of the above observations collected using common characterization techniques have been confirmed with the help of one-pulse ${ }^{1} \mathrm{H}$ and ${ }^{31} \mathrm{P}$ solid-state NMR experiments. The ${ }^{1} \mathrm{H}$ MAS NMR spectra of HA, CHA, CHA-SBF and ACP are combined in Fig. S6. The ${ }^{1}$ H MAS NMR spectrum of HA displays two resonances: one which is very intense and narrow, centered at $\delta\left({ }^{1} \mathrm{H}\right)=0 \mathrm{ppm}$; and another one which is less intense and broader, centered at $\delta\left({ }^{1} \mathrm{H}\right)=5.5$ ppm. The former is attributed to $\mathrm{OH}^{-}$ions in crystalline apatitic environments, while the latter corresponds to water molecules weakly adsorbed onto the surface of the particles [76]. The same observations can be reported for CHA, except that the water and hydroxyl resonances display now similar intensities. Regarding CHA-SBF, the $\mathrm{OH}^{-}$ions deficiency observed by FT-IR spectroscopy is here confirmed. Indeed, the hydroxyl resonance expected at $\delta\left({ }^{1} \mathrm{H}\right)=0 \mathrm{ppm}$ is extremely weak, and appears here only as a shoulder on the right side of the intense water molecules resonance. The ${ }^{1} \mathrm{H}$ MAS NMR spectrum of ACP is dominated by an intense signal centered at $\delta\left({ }^{1} \mathrm{H}\right)=5.3 \mathrm{ppm}$ from adsorbed water molecules. The ${ }^{31} \mathrm{P}$ MAS NMR spectra of HA, CHA, CHA-SBF and ACP are displayed in Fig. S7. All the apatite samples display one single resonance centered around $3 \mathrm{ppm}\left(\right.$ i.e., $\delta\left({ }^{31} \mathrm{P}\right)=2.8 \mathrm{ppm}, 2.9 \mathrm{ppm}$ and $3.2 \mathrm{ppm}$ for HA, CHA and CHA-SBF, respectively), which is typical of $\mathrm{PO}_{4}{ }^{3-}$ ions within crystalline apatitic environments [77-79]. The increase of the ${ }^{31} \mathrm{P}$ chemical shift (Table S1) is known to be correlated with a higher rate of carbonate ions substitution $[77,80,81]$, which is in good agreement with our FT-IR and TGA observations. The ${ }^{31}$ P MAS NMR spectrum of ACP displays one broad single resonance at $\delta\left({ }^{31} \mathrm{P}\right)=3.2 \mathrm{ppm}$, which is then similar to the chemical shift of $\mathrm{PO}_{4}{ }^{3-}$ in apatitic environments. Although all the ${ }^{31} \mathrm{P}$ resonances display almost a similar chemical shift, they all possess very different line widths (LW) (Table S1). Indeed, the ${ }^{31} \mathrm{P}$ 
resonance of the stoichiometric hydroxyapatite $\mathbf{H A}$ is narrow (i.e., $\mathrm{LW}=80 \pm 20 \mathrm{~Hz}$ ), while the

${ }^{31} \mathrm{P}$ resonances of the carbonated hydroxyapatite $\mathbf{C H A}$ and the hydroxyl-deficient carbonated (and potentially substituted with various ionic species) hydroxyapatite CHA-SBF are broader (i.e., LW $=200 \pm 20 \mathrm{~Hz}$ and $370 \pm 20 \mathrm{~Hz}$, respectively). Solid-state NMR spectroscopy probes the local chemical environments surrounding the nucleus of interest. This increasing of the LW therefore tends to show a more important distribution of chemical environments in CHA and CHA-SBF compared to HA. Furthermore, we recently reported that the ${ }^{31} \mathrm{P}$ NMR signatures (lineshape and LW) of CHA-SBF and a fresh bone tissue sample are quite similar [1]. This not only indicates that CHA-SBF mimics the local phosphate environments found in bone mineral, but also shows that CHA-SBF is a suitable model for investigating the bone apatite structure. Finally, the intrinsic structural disorder of $\mathbf{A C P}$ is confirmed from its very broad ${ }^{31} \mathrm{P}$ NMR signature (i.e., $\mathrm{LW}=700 \pm 20 \mathrm{~Hz}$ ).

\subsection{Two-dimensional solid-state NMR}

Two-dimensional (2D) $\left\{{ }^{1} \mathrm{H}\right\}^{31} \mathrm{P}$ Heteronuclear Correlation (HetCor) MAS NMR spectra of HA, CHA, CHA-SBF and ACP appear in Fig. 1. Besides probing the ${ }^{1} \mathrm{H}$ and ${ }^{31} \mathrm{P}$ chemical environments, the great advantage of this technique relies on its ability to reveal the existence of spatial proximities between these two nuclei. The latter appear in the form of correlation peaks in the spectra. The apatitic environments in HA, CHA and CHA-SBF appear at $~ 3.0 \mathrm{ppm}$ in the ${ }^{31} \mathrm{P}$ dimension, and at $0 \mathrm{ppm}$ in the ${ }^{1} \mathrm{H}$ dimension (characteristic of $\mathrm{OH}^{-}$ions in apatitic environments, see Fig. S6). Concerning the biomimetic apatites CHA and CHA-SBF, the ACPlike environments are revealed by the presence of a second phosphorus site that results from the observation of an extra correlation peak which is not observable in the stoichiometric hydroxyapatite HA. This extra correlation peak appears at $\delta\left({ }^{31} \mathrm{P}\right)=3.1 \mathrm{ppm} \& \delta\left({ }^{31} \mathrm{P}\right)=3.2 \mathrm{ppm}$ 
in the ${ }^{31} \mathrm{P}$ dimension for CHA and CHA-SBF, respectively; and spreads along the ${ }^{1} \mathrm{H}$ dimension from $\delta\left({ }^{1} \mathrm{H}\right) \sim 5.5 \mathrm{ppm}$ (rigid water molecules) to $\delta\left({ }^{1} \mathrm{H}\right) \sim 15 \mathrm{ppm}$ attributed to hydrogen-phosphate ions $[15,29,36,37,44,82-87]$. The ${ }^{31} \mathrm{P}$ slices extracted from this extra correlation peak lead to a broad single resonance $\left(\delta\left({ }^{31} \mathrm{P}\right)=3.1 \mathrm{ppm} \& \mathrm{LB}=430 \pm 20 \mathrm{~Hz}\right.$, and $\delta\left({ }^{31} \mathrm{P}\right)=3.2 \mathrm{ppm} \& \mathrm{LB}=$ $660 \pm 20 \mathrm{~Hz}$, for CHA and CHA-SBF, respectively) (Table 1), which presents similar features with the ${ }^{31} \mathrm{P}$ resonance of $\mathbf{A C P}\left(\delta\left({ }^{31} \mathrm{P}\right)=3.2 \mathrm{ppm} \& \mathrm{LB}=700 \pm 20 \mathrm{~Hz}\right)$ (Fig. 2). Furthermore, similar features between the ${ }^{1} \mathrm{H}$ environments detected in ACP and in the ACP-like environments of CHA and CHA-SBF are also revealed with the help of the $2 \mathrm{D}\left\{{ }^{1} \mathrm{H}\right\}{ }^{31} \mathrm{P}$ HetCor NMR experiments: they all have similar ${ }^{1} \mathrm{H}$ signatures in the form of a broad signal in the range of $\delta\left({ }^{1} \mathrm{H}\right) \sim 5.5-15 \mathrm{ppm}$. Similar observations have been reported before on this second phosphorus site detected both in bone mineral and in biomimetic apatites. It was concluded that its structure was closely related to ACP and its chemical composition includes the presence of hydrogen-rich environments (i.e., rigid water molecules and hydrogen-phosphate ions) $[1,28,29,43,44,67,81,87]$.

The 2D $\left\{{ }^{1} \mathrm{H}\right\}{ }^{31} \mathrm{P}$ HetCor MAS NMR spectrum of a mature bone tissue sample is displayed in Fig. 3, together with the spectrum of the physical mixture of HA and ACP powders (HA/ACP mixture). It highlights that the biomimetic apatites (CHA and CHA-SBF) and the HA/ACP mixture possess similar ${ }^{1} \mathrm{H}$ and ${ }^{31} \mathrm{P}$ NMR signatures with the bone tissue sample, and all display the presence of apatitic and amorphous environments. As previously proposed by A. Posner and his colleagues $[21,23,33,88]$, it is clear that the ${ }^{1} \mathrm{H}$ and ${ }^{31} \mathrm{P}$ chemical environments in synthetic ACP are very similar with the ACP-like environments detected both in bone mineral and in biomimetic apatites. Hence, these synthetic samples are good models to investigate if the apatitic and the amorphous environments belong to the same particle in bone mineral. The 2D 
$\left\{{ }^{1} \mathrm{H}\right\}{ }^{31} \mathrm{P}$ HetCor NMR experiments show that the ${ }^{1} \mathrm{H}$ signatures respectively from the crystalline and the amorphous environments are spectrally separated according to their chemical shift: a narrow resonance at $\delta\left({ }^{1} \mathrm{H}\right) \sim 0 \mathrm{ppm}\left(\mathrm{OH}^{-}\right.$ions $)$vs a broad signal in the range of $\delta\left({ }^{1} \mathrm{H}\right) \sim 5.5-15$ ppm (water molecules and $\mathrm{HPO}_{4}{ }^{2-}$ ions). This feature makes possible to investigate the longrange spatial proximities between the three different protonated species with the help of the ${ }^{1} \mathrm{H}$ magnetization EXchange SpectroscopY (EXSY) NMR experiment. This experiment is based on the ${ }^{1} \mathrm{H}$ spin diffusion process, which is driven by the homonuclear ${ }^{1} \mathrm{H}-{ }^{1} \mathrm{H}$ dipolar interactions through zero quantum (flip-flop) and double quanta (flip-flip) transitions [89]. The exchange of magnetization occurs during a given period of time called a mixing time $\left(\mathrm{t}_{\text {mix }}\right)$, which is an adjustable parameter that allows the experimenter to probe long distances through space (up to several nanometers when the ${ }^{1} \mathrm{H}$ single quantum-double quantum experiments are limited to about $8 \AA$ ). The ${ }^{1} \mathrm{H}$ EXSY NMR experiment is commonly acquired in two-dimensions as a ${ }^{1} \mathrm{H}$ ${ }^{1} \mathrm{H}$ homonuclear correlation spectrum, where the off-diagonal cross-peaks (i.e., exchange crosspeaks) reveal the existence of spatial continuities between the protonated species and, as corollary confirm their presence within the same particle. This experiment has been widely used to assess the phase separation of crystalline and amorphous domains in polymers [90]. However, the one-pulse ${ }^{1} \mathrm{H}$ MAS NMR spectrum recorded from an intact bone tissue sample is dominated by the free water molecules, the organic matrix and the lipids from the cells [76,91]. This prevents the ${ }^{1} \mathrm{H}$ EXSY NMR experiment to directly probe the spatial continuity between the protonated species in bone mineral from an intact bone tissue sample.

To circumvent this issue, a combined approach can be used by adding a filtering step, namely a Double $\mathrm{CP}{ }^{1} \mathrm{H} \rightarrow{ }^{31} \mathrm{P} \rightarrow{ }^{1} \mathrm{H}$ NMR experiment prior to the EXSY NMR experiment (Fig. S1). Such an approach has been successfully performed before to study the mineral/organic 
interface in surfactant-silica (i.e., Double $\mathrm{CP}{ }^{1} \mathrm{H} \rightarrow{ }^{29} \mathrm{Si} \rightarrow{ }^{1} \mathrm{H}$ ) [64] and liposome-silica (i.e., Double $\mathrm{CP}{ }^{1} \mathrm{H} \rightarrow{ }^{31} \mathrm{P} \rightarrow{ }^{1} \mathrm{H}$ and ${ }^{1} \mathrm{H} \rightarrow{ }^{29} \mathrm{Si} \rightarrow{ }^{1} \mathrm{H}$ ) [92] hybrid materials. This Double $\mathrm{CP}$ ${ }^{1} \mathrm{H} \rightarrow{ }^{31} \mathrm{P} \rightarrow{ }^{1} \mathrm{H}$ NMR experiment consists of two consecutive CP magnetization transfers: (i) a first magnetization transfer from ${ }^{1} \mathrm{H}$ to ${ }^{31} \mathrm{P}$ (characterized by a contact time $\left.\mathrm{t}_{\mathrm{c}} 1\right)$, followed by $($ ii $)$ a second magnetization transfer from ${ }^{31} \mathrm{P}$ back to ${ }^{1} \mathrm{H}$ (characterized by a contact time $\mathrm{t}_{\mathrm{cp}} 2$ ). The advantage of this Double $\mathrm{CP}{ }^{1} \mathrm{H} \rightarrow{ }^{31} \mathrm{P} \rightarrow{ }^{1} \mathrm{H}$ NMR experiment compared to an inverse-CP ${ }^{31} \mathrm{P} \rightarrow{ }^{1} \mathrm{H}$ NMR experiment (which has already been used to study a nanocrystalline apatite sample [93]) relies on the fact that the Double $\mathrm{CP}$ experiment is driven by the $T_{1}\left({ }^{1} \mathrm{H}\right)$ instead of the $T_{1}\left({ }^{31} \mathrm{P}\right)$ which is much more longer. The two contact times, i.e., the time during which the magnetization transfer takes place between the ${ }^{1} \mathrm{H}$ and ${ }^{31} \mathrm{P}$ spins, have been optimized to enhance the signal from the ACP-like environments: $\mathrm{t}_{\mathrm{cp}} 1=1000 \mu \mathrm{s}$, and $\mathrm{t}_{\mathrm{cp}} 2=850 \mu \mathrm{s}$. The ${ }^{1} \mathrm{H}$ MAS NMR spectra of HA/ACP mixture, CHA and CHA-SBF recorded with the help of this Double $\mathrm{CP}{ }^{1} \mathrm{H} \rightarrow{ }^{31} \mathrm{P} \rightarrow{ }^{1} \mathrm{H}$ experiment are highly resolved compared to the one-pulse ${ }^{1} \mathrm{H}$ MAS NMR spectra - and all the three protonated species $\left(\mathrm{OH}^{-}, \mathrm{H}_{2} \mathrm{O}\right.$ and $\left.\mathrm{HPO}_{4}{ }^{2-}\right)$ are easily observable at $\delta\left({ }^{1} \mathrm{H}\right)=0$ ppm, $\delta\left({ }^{1} \mathrm{H}\right) \sim 5.5 \mathrm{ppm}$ and in the range of $\delta\left({ }^{1} \mathrm{H}\right)=10-15 \mathrm{ppm}$, respectively (Fig. S8). The $2 \mathrm{D}{ }^{1} \mathrm{H}^{-}{ }^{1} \mathrm{H}$ EXSY NMR spectra ( $\mathrm{t}_{\text {mix }}=10 \mu$ s and $10 \mathrm{~ms}$ ) of the biomimetic apatites CHA and CHA-SBF recorded after the Double $\mathrm{CP}{ }^{1} \mathrm{H} \rightarrow{ }^{31} \mathrm{P} \rightarrow{ }^{1} \mathrm{H}$ filtering step $\left({ }^{1} \mathrm{H}\right.$ Double CP EXSY MAS NMR experiment, Fig. S1) appear in Fig. 4. For a short mixing time ( $\left.\mathrm{t}_{\text {mix }}=10 \mu \mathrm{s}\right)$, no magnetization exchange is evidenced between any of the three spin systems (i.e., $\mathrm{OH}^{-}$, rigid $\mathrm{H}_{2} \mathrm{O}$ and $\mathrm{HPO}_{4}{ }^{2-}$ ), thus giving a reference spectrum. However, for $\mathrm{t}_{\mathrm{mix}}=10 \mathrm{~ms}$, magnetization exchanges are observable between all the three ${ }^{1} \mathrm{H}$ spin systems in the form of strong exchange cross-peaks (see the red dashed lines) in both CHA and CHA-SBF. These magnetization exchanges provide evidence of the continuity of the apatitic and ACP-like environments within 
the same particle in these biomimetic apatites - one of the two scenarios likely to happen in bone mineral. The second potential scenario, which consists of the presence of apatite crystals and amorphous particles apart has been investigated with the help of the physical mixture of $\mathbf{H A}$ and ACP powders (HA/ACP mixture). A recent solid-state NMR investigation has estimated that approximately $45 \%$ of the ${ }^{31} \mathrm{P}$ nuclei in bone mineral were localized within the ACP-like environments [81]. This is the reason why the physical mixture of $\mathbf{H A}$ and ACP was made by mixing the same mass of HA and ACP powders, giving a 50:50 w/w mix ratio. TEM images of this physical mixture are depicted in Fig. S10. Microsized aggregates of HA and ACP particles are observed even if, locally, some HA and ACP particles are close to each other. In the bone tissue, the transient amorphous particles (if they exist) are suspected to be mainly present in the so-called "mineralizing front" created by the successive action of the osteoclasts and then the osteoblasts, responsible of the renewing process of the bone tissue. This "mineralizing front" is far away (several microns) from the apatite bone crystals located in the mature part of the tissue [94]. Thus, on that point-of-view, microsized domains of HA and ACP particles are actually close to the in vivo conditions. The $2 \mathrm{D}{ }^{1} \mathrm{H}$ Double CP EXSY MAS NMR spectra $\left(\mathrm{t}_{\mathrm{mix}}=10 \mu \mathrm{s}\right.$ and $10 \mathrm{~ms}$ ) of this physical mixture appear in Fig. 5. In these conditions, regardless of the mixing time used, no exchange cross-peak is observed between the $\mathrm{OH}^{-}$(from $\mathbf{H A}$ ) and the $\mathrm{H}_{2} \mathrm{O} / \mathrm{HPO}_{4}{ }^{2-}$ (from ACC) in the ${ }^{1} \mathrm{H}-{ }^{1} \mathrm{H}$ spin connectivity spectra. As expected, this shows the absence of continuity between the crystalline and the amorphous environments. Furthermore, the magnetization exchange between the rigid $\mathrm{H}_{2} \mathrm{O}$ and the $\mathrm{HPO}_{4}{ }^{2-}$ that are both present in $\mathbf{A C C}$ was expected, and is observable (see the red dashed lines).

The same approach has been performed for an intact sample of mature bone tissue originating from a two-year-old sheep. This bone tissue sample displays a similar 1D 
${ }^{1} \mathrm{H} \rightarrow{ }^{31} \mathrm{P} \rightarrow{ }^{1} \mathrm{H}$ Double CP NMR spectrum (Fig. S9) as those of the model samples (i.e., CHA and CHA-SBF). The 2D ${ }^{1} \mathrm{H}$ Double CP EXSY MAS NMR experiment has also been applied (Fig. 6). After a mixing time of $10 \mathrm{~ms}$, magnetization exchanges are observable between the three ${ }^{1} \mathrm{H}$ spin systems in bone mineral in the form of strong exchange cross-peaks (see the red dashed lines), as was the case for the biomimetic apatites CHA and CHA-SBF. The ${ }^{1} \mathrm{H}-{ }^{1} \mathrm{H}$ spin connectivity NMR spectra reported from the two-different free-organic biomimetic apatites confirm that the protonated species detected in the bone tissue sample are exclusively related to the mineral - that excludes any artefacts that could be due to the detection of phosphorus-containing organic molecules as phospholipids or phosphorylated proteins.

Our results unambiguously show that a single bone mineral platelet is constituted by the addition of crystalline apatitic environments and ACP-like environments. Further, a recent study not only shows that these ACP-like environments are very hydrophilic, but also demonstrates that its proton species $\left(\mathrm{H}_{2} \mathrm{O}\right.$ and $\left.\mathrm{HPO}_{4}{ }^{2-}\right)$ are readily accessible and exchangeable by $\mathrm{D}_{2} \mathrm{O}$ [1]. These observations support the hypothesis that these ACP-like environments stand at the surface of bone mineral particles in the form of a mineral surface layer. In addition, the highly hydrophilic properties of this amorphous surface layer leads to the formation of a rigid hydration shell of bound water surrounding the bone mineral particles in vivo [1]. It was shown that this hydration shell, with no need of bioorganic molecules (i.e., collagen, non-collagenous proteins, or proteoglycans), plays a significant role by locally structuring the bone apatite platelets [1]. Further, it was proposed that this local behavior might impact the macroscopic mechanical properties of bone tissue $[41,95]$.

At last, the present study confirms the presence of an ACP-like surface layer that coats the bone apatite particles in bone mineral of a two-year-old sheep bone tissue sample - but it 
does not exclude the presence, in addition, of a transient amorphous calcium phosphate phase present at the early stages of bone mineral deposition. Further, we analyzed the ${ }^{1} \mathrm{H}-{ }^{1} \mathrm{H}$ spin diffusion intensities in the 2D ${ }^{1} \mathrm{H}$ Double CP EXSY MAS NMR spectra of CHA-SBF and the bone tissue sample (Fig. S11). After $10 \mathrm{~ms}$ for the bone sample, we found that $45 \%$ of the total ${ }^{1} \mathrm{H}$ magnetization from the ACP-like environments have been exchanged with the $\mathrm{OH}^{-}$from the apatitic environments. For the biomimetic apatite CHA-SBF, the proportion is a little bit less as we found $36 \%$. Interestingly, CHA-SBF does not possess any ACP independent phase but only an ACP-like layer at the surface of the apatite crystals. Thus, although it seems not possible to show that all ${ }^{1} \mathrm{H}$ spins from the ACP environments are in contact with the apatitic environments in bone mineral, this result is a good indication that an independent transient ACP precursor phase in bone (if it exists) is a minor component of our bone tissue sample.

\section{Conclusions}

Our results demonstrate that the crystalline apatitic and the ACP-like environments that were detected both in two biomimetic apatites and in bone mineral belong to the same particle. This conclusion supports and reconfirms the accuracy of the existing model that describes the bone apatite and the biomimetic apatite particles: a nanosized platelet constituted by a crystalline core in the form of hydroxyapatite coated by an ACP-like surface layer.

The ACP-like surface layer thus interacts with all the extracellular components (i.e., water, non-collagenous proteins, proteoglycans, collagen and the mineral itself) and cells. The latter is therefore involved in all the biochemical, biophysical and physico-chemical reactions associated with bone mineral; and accordingly, it is clear that the ACP-like surface layer has strong implication on bone tissue biogenesis and regeneration. Future work should make an 
effort to describe the biomolecules/mineral interface, and our study emphasizes the need to consider a biomolecules/ACP interface instead of a biomolecules/crystalline apatite interface. 


\section{Disclosures}

The authors declare that there are no conflicts of interest.

\section{Acknowledgements}

We thank IMM Recherche, especially L. Behr, for providing the bone samples, and P. Le Griel for TEM observations. We thank the laboratory of excellence (Labex) Matisse for supporting part of this research work.

\section{References}

[1] Y. Wang, S. Von Euw, F.M. Fernandes, S. Cassaignon, M. Selmane, G. Laurent, G. PehauArnaudet, C. Coelho, L. Bonhomme-Coury, M.-M. Giraud-Guille, F. Babonneau, T. Azaïs, N. Nassif, Water-mediated structuring of bone apatite, Nat Mater. 12 (2013) 1144-1153.

[2] N. Nassif, N. Pinna, N. Gehrke, M. Antonietti, C. Jäger, H. Cölfen, Amorphous layer around aragonite platelets in nacre, Proc. Natl. Acad. Sci. U. S. A. 102 (2005) 1265312655.

[3] E. Beniash, R.A. Metzler, R.S.K. Lam, P.U.P.A. Gilbert, Transient amorphous calcium phosphate in forming enamel, J. Struct. Biol. 166 (2009) 133-143.

[4] J. Mahamid, A. Sharir, L. Addadi, S. Weiner, Amorphous calcium phosphate is a major component of the forming fin bones of zebrafish: Indications for an amorphous precursor phase, Proc. Natl. Acad. Sci. 105 (2008) 12748-12753.

[5] R.T. DeVol, C.-Y. Sun, M.A. Marcus, S.N. Coppersmith, S.C.B. Myneni, P.U.P.A. Gilbert, Nanoscale Transforming Mineral Phases in Fresh Nacre, J. Am. Chem. Soc. 137 (2015) 13325-13333.

[6] Y. Politi, T. Arad, E. Klein, S. Weiner, L. Addadi, Sea Urchin Spine Calcite Forms via a Transient Amorphous Calcium Carbonate Phase, Science. 306 (2004) 1161-1164.

[7] S. Raz, P.C. Hamilton, F.H. Wilt, S. Weiner, L. Addadi, The Transient Phase of Amorphous Calcium Carbonate in Sea Urchin Larval Spicules: The Involvement of Proteins and Magnesium Ions in Its Formation and Stabilization, Adv. Funct. Mater. 13 (2003) 480-486.

[8] W.F. de Jong, La Substance Minérale Dans les Os, Recl. Trav. Chim. Pays-Bas. 45 (1926) 445-448.

[9] A.L. Boskey, Amorphous Calcium Phosphate: The Contention of Bone, J. Dent. Res. 76 (1997) 1433-1436.

[10] M.J. Glimcher, Bone: Nature of the Calcium Phosphate Crystals and Cellular, Structural, and Physical Chemical Mechanisms in Their Formation, Rev. Mineral. Geochem. 64 (2006) 223-282.

[11] C. Rey, C. Combes, C. Drouet, M.J. Glimcher, Bone mineral: update on chemical composition and structure, Osteoporos. Int. 20 (2009) 1013-1021.

[12] S. V. Dorozhkin, Amorphous Calcium Orthophosphates: Nature, Chemistry and Biomedical Applications, Int. J. Mater. Chem. 2 (2012) 19-46.

[13] S.J. Eppell, W. Tong, J.L. Katz, L. Kuhn, M.J. Glimcher, Shape and size of isolated bone mineralites measured using atomic force microscopy, J. Orthop. Res. Off. Publ. Orthop. Res. Soc. 19 (2001) 1027-1034.

[14] H.M. Kim, C. Rey, M.J. Glimcher, Isolation of calcium-phosphate crystals of bone by nonaqueous methods at low temperature, J. Bone Miner. Res. Off. J. Am. Soc. Bone Miner. Res. 10 (1995) 1589-1601. 
[15] G. Cho, Y. Wu, J.L. Ackerman, Detection of hydroxyl ions in bone mineral by solid-state NMR spectroscopy, Science. 300 (2003) 1123-1127.

[16] R. Legros, N. Balmain, G. Bonel, Age-related changes in mineral of rat and bovine cortical bone, Calcif. Tissue Int. 41 (1987) 137-144.

[17] C.-K. Loong, C. Rey, L.T. Kuhn, C. Combes, Y. Wu, S.-H. Chen, M.J. Glimcher, Evidence of hydroxyl-ion deficiency in bone apatites: an inelastic neutron-scattering study, Bone. 26 (2000) 599-602.

[18] W.F. Neuman, M.W. Neuman, The Nature of the Mineral Phase of Bone., Chem. Rev. 53 (1953) $1-45$.

[19] R.A. Robinson, M.L. Watson, Crystal-collagen relationships in bone as observed in the electron microscope. III. Crystal and collagen morphology as a function of age., Ann. N. Y. Acad. Sci. 60 (1955) 596-630.

[20] E.D. Eanes, I.H. Gillessen, A.S. Posner, Intermediate States in the Precipitation of Hydroxyapatite, Nature. 208 (1965) 365-367.

[21] R.A. Harper, A.S. Posner, Measurement of non-crystalline calcium phosphate in bone mineral, Proc. Soc. Exp. Biol. Med. Soc. Exp. Biol. Med. N. Y. N. 122 (1966) 137-142.

[22] J.D. Termine, Amorphous calcium phosphate: the second mineral of bone. Ph.D. Thesis, Cornell University, 1966.

[23] J.D. Termine, A.S. Posner, Amorphous/crystalline interrelationships in bone mineral, Calcif. Tissue Res. 1 (1967) 8-23.

[24] J.D. Termine, A.S. Posner, Infrared analysis of rat bone: age dependency of amorphous and crystalline mineral fractions, Science. 153 (1966) 1523-1525.

[25] L.C. Bonar, A.H. Roufosse, W.K. Sabine, M.D. Grynpas, M.J. Glimcher, X-ray diffraction studies of the crystallinity of bone mineral in newly synthesized and density fractionated bone, Calcif. Tissue Int. 35 (1983) 202-209.

[26] M.J. Glimcher, L.C. Bonar, M.D. Grynpas, W.J. Landis, A.H. Roufosse, Recent studies of bone mineral: Is the amorphous calcium phosphate theory valid?, J. Cryst. Growth. 53 (1981) 100-119.

[27] M.D. Grynpas, L.C. Bonar, M.J. Glimcher, Failure to detect an amorphous calciumphosphate solid phase in bone mineral: A radial distribution function study, Calcif. Tissue Int. 36 (1984) 291-301.

[28] R.A. Santos, R.A. Wind, C.E. Bronnimann, ${ }^{1} \mathrm{H}$ CRAMPS and ${ }^{1} \mathrm{H}-{ }^{31} \mathrm{P}$ HetCor experiments on bone, bone mineral, and model calcium phosphate phases, J. Magn. Reson. B. 105 (1994) 183-187.

[29] Y. Wu, M.J. Glimcher, C. Rey, J.L. Ackerman, A unique protonated phosphate group in bone mineral not present in synthetic calcium phosphates. Identification by phosphorus-31 solid state NMR spectroscopy, J. Mol. Biol. 244 (1994) 423-435.

[30] J. Arends, J. Christoffersen, M.R. Christoffersen, H. Eckert, B.O. Fowler, J.C. Heughebaert, G.H. Nancollas, J.P. Yesinowski, S.J. Zawacki, A calcium hydroxyapatite precipitated from an aqueous solution, J. Cryst. Growth. 84 (1987) 515-532.

[31] N. Pleshko, A. Boskey, R. Mendelsohn, Novel infrared spectroscopic method for the determination of crystallinity of hydroxyapatite minerals, Biophys. J. 60 (1991) 786-793.

[32] J.D. Termine, A.S. Posner, Infra-Red Determination of the Percentage of Crystallinity in Apatitic Calcium Phosphates, Nature. 211 (1966) 268-270.

[33] A.S. Posner, F. Betts, Synthetic amorphous calcium phosphate and its relation to bone mineral structure, Acc. Chem. Res. 8 (1975) 273-281. 
[34] D. Eichert, M. Salomé, M. Banu, J. Susini, C. Rey, Preliminary characterization of calcium chemical environment in apatitic and non-apatitic calcium phosphates of biological interest by X-ray absorption spectroscopy, Spectrochim. Acta Part B At. Spectrosc. 60 (2005) 850858.

[35] T. Isobe, S. Nakamura, R. Nemoto, M. Antonietti, H. Sfihi, Solid-State Double Nuclear Magnetic Resonance Study of the Local Structure of Calcium Phosphate Nanoparticles Synthesized by a Wet-Mechanochemical Reaction, J. Phys. Chem. B. 106 (2002) 5169_ 5176.

[36] A. Kaflak-Hachulska, A. Samoson, W. Kolodziejski, ${ }^{1} \mathrm{H}$ MAS and ${ }^{1} \mathrm{H}-->{ }^{31} \mathrm{P}$ CP/MAS NMR Study of Human Bone Mineral, Calcif. Tissue Int. 73 (2003) 476-486.

[37] Y. Wu, J.L. Ackerman, H.-M. Kim, C. Rey, A. Barroug, M.J. Glimcher, Nuclear magnetic resonance spin-spin relaxation of the crystals of bone, dental enamel, and synthetic hydroxyapatites, J. Bone Miner. Res. Off. J. Am. Soc. Bone Miner. Res. 17 (2002) $472-$ 480.

[38] S. Cazalbou, C. Combes, D. Eichert, C. Rey, M.J. Glimcher, Poorly crystalline apatites: evolution and maturation in vitro and in vivo, J. Bone Miner. Metab. 22 (2004) 310-317.

[39] W.F. Neuman, T.Y. Toribara, B.J. Mulryan, The Surface Chemistry of Bone. IX. Carbonate: Phosphate Exchange, J. Am. Chem. Soc. 78 (1956) 4263-4266.

[40] W.F. Neuman, B.J. Mulryan, Synthetic hydroxyapatite crystals. 3. The carbonate system, Calcif. Tissue Res. 1 (1967) 94-104.

[41] M. Duer, A. Veis, Bone mineralization: Water brings order, Nat. Mater. 12 (2013) 10811082.

[42] D. Farlay, G. Panczer, C. Rey, P. Delmas, G. Boivin, Mineral maturity and crystallinity index are distinct characteristics of bone mineral, J. Bone Miner. Metab. 28 (2010) 433445.

[43] C. Jäger, S. Maltsev, A. Karrasch, Progress of Structural Elucidation of Amorphous Calcium Phosphate(ACP)and Hydroxyapatite (HAp): Disorder and Surfaces as Seen by Solid State NMR, Key Eng. Mater. 309-311 (2006) 69-72.

[44] C. Jäger, T. Welzel, W. Meyer-Zaika, M. Epple, A solid-state NMR investigation of the structure of nanocrystalline hydroxyapatite, Magn. Reson. Chem. 44 (2006) 573-580.

[45] C. Rey, C. Combes, C. Drouet, H. Sfihi, A. Barroug, Physico-chemical properties of nanocrystalline apatites: Implications for biominerals and biomaterials, Mater. Sci. Eng. C. 27 (2007) 198-205.

[46] S.-J. Huang, Y.-L. Tsai, Y.-L. Lee, C.-P. Lin, J.C.C. Chan, Structural Model of Rat Dentin Revisited, Chem. Mater. 21 (2009) 2583-2585.

[47] Y.-H. Tseng, Y.-L. Tsai, T.W.. . Tsai, C.-P. Lin, S.-H. Huang, C.-Y. Mou, J.C.C. Chan, Double-quantum filtered heteronuclear correlation spectroscopy under magic angle spinning, Solid State Nucl. Magn. Reson. 31 (2007) 55-61.

[48] Y.-H. Tseng, Y.-L. Tsai, T.W.T. Tsai, J.C.H. Chao, C.-P. Lin, S.-H. Huang, C.-Y. Mou, J.C.C. Chan, Characterization of the Phosphate Units in Rat Dentin by Solid-State NMR Spectroscopy, Chem. Mater. 19 (2007) 6088-6094.

[49] L. Bertinetti, A. Tampieri, E. Landi, C. Ducati, P.A. Midgley, S. Coluccia, G. Martra, Surface Structure, Hydration, and Cationic Sites of Nanohydroxyapatite: UHR-TEM, IR, and Microgravimetric Studies, J. Phys. Chem. C. 111 (2007) 4027-4035. 
[50] Y. Sakhno, L. Bertinetti, M. Iafisco, A. Tampieri, N. Roveri, G. Martra, Surface Hydration and Cationic Sites of Nanohydroxyapatites with Amorphous or Crystalline Surfaces: A Comparative Study, J. Phys. Chem. C. 114 (2010) 16640-16648.

[51] O. Borkiewicz, J. Rakovan, C.L. Cahill, Time-resolved in situ studies of apatite formation in aqueous solutions, Am. Mineral. 95 (2010) 1224-1236.

[52] F. Castro, A. Ferreira, F. Rocha, A. Vicente, J. António Teixeira, Characterization of intermediate stages in the precipitation of hydroxyapatite at $37^{\circ} \mathrm{C}$, Chem. Eng. Sci. 77 (2012) 150-156.

[53] A. Dey, P.H.H. Bomans, F.A. Müller, J. Will, P.M. Frederik, G. de With, N.A.J.M. Sommerdijk, The role of prenucleation clusters in surface-induced calcium phosphate crystallization, Nat. Mater. 9 (2010) 1010-1014.

[54] W.J.E.M. Habraken, J. Tao, L.J. Brylka, H. Friedrich, L. Bertinetti, A.S. Schenk, A. Verch, V. Dmitrovic, P.H.H. Bomans, P.M. Frederik, J. Laven, P. van der Schoot, B. Aichmayer, G. de With, J.J. DeYoreo, N.A.J.M. Sommerdijk, Ion-association complexes unite classical and non-classical theories for the biomimetic nucleation of calcium phosphate, Nat. Commun. 4 (2013) 1507.

[55] G. He, T. Dahl, A. Veis, A. George, Nucleation of apatite crystals in vitro by selfassembled dentin matrix protein 1, Nat. Mater. 2 (2003) 552-558.

[56] W. He, P. Kjellin, F. Currie, P. Handa, C.S. Knee, J. Bielecki, L.R. Wallenberg, M. Andersson, Formation of Bone-like Nanocrystalline Apatite Using Self-Assembled Liquid Crystals, Chem. Mater. 24 (2012) 892-902.

[57] F. Nudelman, K. Pieterse, A. George, P.H.H. Bomans, H. Friedrich, L.J. Brylka, P.A.J. Hilbers, G. de With, N.A.J.M. Sommerdijk, The role of collagen in bone apatite formation in the presence of hydroxyapatite nucleation inhibitors, Nat. Mater. 9 (2010) 1004-1009.

[58] G.B. Ramírez-Rodríguez, J.M. Delgado-López, J. Gómez-Morales, Evolution of calcium phosphate precipitation in hanging drop vapor diffusion by in situ Raman microspectroscopy, CrystEngComm. 15 (2013) 2206.

[59] T. Tsuji, K. Onuma, A. Yamamoto, M. Iijima, K. Shiba, Direct transformation from amorphous to crystalline calcium phosphate facilitated by motif-programmed artificial proteins, Proc. Natl. Acad. Sci. 105 (2008) 16866-16870.

[60] W.J. Landis, M.J. Glimcher, Electron optical and analytical observations of rat growth plate cartilage prepared by ultracryomicrotomy: the failure to detect a mineral phase in matrix vesicles and the identification of heterodispersed particles as the initial solid phase of calcium phosphate deposited in the extracellular matrix, J. Ultrastruct. Res. 78 (1982) 227268.

[61] H.A. Lowenstam, S. Weiner, Transformation of amorphous calcium phosphate to crystalline dahillite in the radular teeth of chitons, Science. 227 (1985) 51-53.

[62] J. Mahamid, B. Aichmayer, E. Shimoni, R. Ziblat, C. Li, S. Siegel, O. Paris, P. Fratzl, S. Weiner, L. Addadi, Mapping amorphous calcium phosphate transformation into crystalline mineral from the cell to the bone in zebrafish fin rays, Proc. Natl. Acad. Sci. 107 (2010) 6316-6321.

[63] A. Akiva, G. Malkinson, A. Masic, M. Kerschnitzki, M. Bennet, P. Fratzl, L. Addadi, S. Weiner, K. Yaniv, On the pathway of mineral deposition in larval zebrafish caudal fin bone, Bone. 75 (2015) 192-200. 
[64] N. Baccile, G. Laurent, C. Bonhomme, P. Innocenzi, F. Babonneau, Solid-State NMR Characterization of the Surfactant-Silica Interface in Templated Silicas: Acidic versus Basic Conditions, Chem. Mater. 19 (2007) 1343-1354.

[65] S. Takemoto, Y. Kusudo, K. Tsuru, S. Hayakawa, A. Osaka, S. Takashima, Selective protein adsorption and blood compatibility of hydroxy-carbonate apatites, J. Biomed. Mater. Res. A. 69 (2004) 544-551.

[66] J.C. Heughebaert, Contribution a l'etude de l'evolution des orthophosphates de calcium precipites amorphes en orthophosphates apatitiques, Ph.D. Thesis, INP Toulouse, 1977.

[67] N. Nassif, F. Martineau, O. Syzgantseva, F. Gobeaux, M. Willinger, T. Coradin, S. Cassaignon, T. Azaïs, M.M. Giraud-Guille, In Vivo Inspired Conditions to Synthesize Biomimetic Hydroxyapatite, Chem. Mater. 22 (2010) 3653-3663.

[68] S.H. Rhee, J. Tanaka, Hydroxyapatite formation on cellulose cloth induced by citric acid, J. Mater. Sci. Mater. Med. 11 (2000) 449-452.

[69] N.C. Nielsen, H. Bildsoe, H.J. Jakobsen, M.H. Levitt, Double-quantum homonuclear rotary resonance: Efficient dipolar recovery in magic-angle spinning nuclear magnetic resonance, J. Chem. Phys. 101 (1994) 1805.

[70] C.S. Yannoni, High-resolution NMR in solids: the CPMAS experiment, Acc. Chem. Res. 15 (1982) 201-208.

[71] C. Combes, C. Rey, Amorphous calcium phosphates: Synthesis, properties and uses in biomaterials, Acta Biomater. 6 (2010) 3362-3378.

[72] S.V. Dorozhkin, Amorphous calcium (ortho)phosphates, Acta Biomater. 6 (2010) 44574475.

[73] C. Rey, B. Collins, T. Goehl, I.R. Dickson, M.J. Glimcher, The carbonate environment in bone mineral: a resolution-enhanced Fourier Transform Infrared Spectroscopy Study, Calcif. Tissue Int. 45 (1989) 157-164.

[74] D. Tadic, F. Peters, M. Epple, Continuous synthesis of amorphous carbonated apatites, Biomaterials. 23 (2002) 2553-2559.

[75] L.D. Mkukuma, J.M.S. Skakle, I.R. Gibson, C.T. Imrie, R.M. Aspden, D.W.L. Hukins, Effect of the proportion of organic material in bone on thermal decomposition of bone mineral: an investigation of a variety of bones from different species using thermogravimetric analysis coupled to mass spectrometry, high-temperature X-ray diffraction, and Fourier transform infrared spectroscopy, Calcif. Tissue Int. 75 (2004) 321328.

[76] J.P. Yesinowski, H. Eckert, Hydrogen environments in calcium phosphates: proton MAS NMR at high spinning speeds, J. Am. Chem. Soc. 109 (1987) 6274-6282.

[77] W.P. Aue, A.H. Roufosse, M.J. Glimcher, R.G. Griffin, Solid-state phosphorus-31 nuclear magnetic resonance studies of synthetic solid phases of calcium phosphate: potential models of bone mineral, Biochemistry (Mosc.). 23 (1984) 6110-6114.

[78] W.P. Rothwell, J.S. Waugh, J.P. Yesinowski, High-resolution variable-temperature phosphorus-31 NMR of solid calcium phosphates, J. Am. Chem. Soc. 102 (1980) 26372643.

[79] A.H. Roufosse, W.P. Aue, J.E. Roberts, M.J. Glimcher, R.G. Griffin, Investigation of mineral phases of bone by solid-state phosphorus-31 magic-angle sample-spinning nuclear magnetic resonance, Biochemistry (Mosc.). 23 (1984) 6115-6120.

[80] W. Kolodziejski, Solid-State NMR Studies of Bone, in: New Tech. Solid-State NMR, Springer Berlin Heidelberg, Berlin, Heidelberg, 2005: pp. 235-270. 
[81] Y. Wang, S. Von Euw, G. Laurent, C. Crevant, L. Bonhomme-Coury, M.-M. GiraudGuille, F. Babonneau, N. Nassif, T. Azaïs, Impact of collagen confinement vs. ionic substitutions on the local disorder in bone and biomimetic apatites, Mater Horiz. 1 (2014) 224-231.

[82] A. Kaflak, D. Chmielewski, A. Górecki, W. Kolodziejski, Kinetics of ${ }^{1} \mathrm{H} \rightarrow{ }^{31} \mathrm{P}$ crosspolarization in human trabecular bone, Solid State Nucl. Magn. Reson. 10 (1998) 191-195.

[83] A. Kaflak, W. Kolodziejski, Kinetics of ${ }^{1} \mathrm{H} \rightarrow{ }^{31} \mathrm{P}$ NMR cross-polarization in bone apatite and its mineral standards, Magn. Reson. Chem. 46 (2008) 335-341.

[84] V. Klimavicius, A. Kareiva, V. Balevicius, Solid-State NMR Study of Hydroxyapatite Containing Amorphous Phosphate Phase and Nanostructured Hydroxyapatite: Cut-Off Averaging of CP-MAS Kinetics and Size Profiles of Spin Clusters, J. Phys. Chem. C. 118 (2014) 28914-28921.

[85] F. Pourpoint, C. Gervais, L. Bonhomme-Coury, T. Azaïs, C. Coelho, F. Mauri, B. Alonso, F. Babonneau, C. Bonhomme, Calcium Phosphates and Hydroxyapatite: Solid-State NMR Experiments and First-Principles Calculations, Appl. Magn. Reson. 32 (2007) 435-457.

[86] A.J. Taylor, E. Rendina, B.J. Smith, D.H. Zhou, Analyses of mineral specific surface area and hydroxyl substitution for intact bone, Chem. Phys. Lett. 588 (2013) 124-130.

[87] S. Von Euw, Bone biomineralization: from the structural characterization of the mineral to its 3D organization. Ph.D. Thesis, UPMC Univ Paris 06, 2014.

[88] F. Betts, N.C. Blumenthal, A.S. Posner, Bone mineralization, J. Cryst. Growth. 53 (1981) 63-73.

[89] J. Keeler, Understanding NMR spectroscopy, 2nd ed, John Wiley and Sons, Chichester, U.K, 2010.

[90] K. Schmidt-Rohr, H.W. Spiess, Multidimensional Solid-State NMR and Polymers, Elsevier Science, Burlington, 1994.

[91] J.L. Miquel, L. Facchini, A.P. Legrand, X. Marchandise, P. Lecouffe, M. Chanavaz, M. Donazzan, C. Rey, J. Lernaitre, Characterisation and conversion study into natural living bone of calcium phosphate bioceramics by solid state NMR spectroscopy, Clin. Mater. 5 (1990) 115-125.

[92] N. Folliet, C. Roiland, S. Bégu, A. Aubert, T. Mineva, A. Goursot, K. Selvaraj, L. Duma, F. Tielens, F. Mauri, G. Laurent, C. Bonhomme, C. Gervais, F. Babonneau, T. Azaïs, Investigation of the Interface in Silica-Encapsulated Liposomes by Combining Solid State NMR and First Principles Calculations, J. Am. Chem. Soc. 133 (2011) 16815-16827.

[93] J. Kolmas, W. Kolodziejski, Inverse ${ }^{31} \mathrm{P} \rightarrow{ }^{1} \mathrm{H}$ NMR cross-polarization in hydrated nanocrystalline calcium hydroxyapatite, Chem. Phys. Lett. 554 (2012) 128-132.

[94] Glimcher, M. J. in Medical Mineralogy and Geochemistry Vol. 64 (eds Sahai, N. \& Schoonen, M. A. A.) 223-282 (Reviews in Mineralogy \& Geochemistry, 2006)

[95] M. Granke, M.D. Does, J.S. Nyman, The Role of Water Compartments in the Material Properties of Cortical Bone, Calcif. Tissue Int. 97 (2015) 292-307. 


\section{Figures captions}

Figure 1. Two-dimensional $\left\{{ }^{1} \mathrm{H}\right\}{ }^{31} \mathrm{P}$ HetCor MAS NMR spectra of the synthetic calcium phosphate samples: stoichiometric apatite (HA); biomimetic apatites (CHA and CHA-SBF); and amorphous calcium phosphate $(\mathbf{A C P})$. Contact time, $\mathrm{t}_{\mathrm{CP}}=1 \mathrm{~ms}$ for $\mathbf{H A}, \mathbf{C H A}$ and CHA-SBF and $\mathrm{t}_{\mathrm{CP}}=2 \mathrm{~ms}$ for $\mathbf{A C P}$.

Figure 2. ${ }^{31} \mathrm{P}$ NMR signatures relative to the ACP-like environments (full line) and the crystalline apatitic environments (dashed line) found in CHA and CHA-SBF $\left(\right.$ contact time, $\mathrm{t}_{\mathrm{CP}}=$ $1 \mathrm{~ms}$ ), extracted from the 2D $\left\{{ }^{1} \mathrm{H}\right\}{ }^{31} \mathrm{P}$ HetCor NMR spectra of Fig. 1; as well as the ${ }^{31} \mathrm{P}$ CP MAS NMR spectrum of $\mathbf{A C P}$ (contact time, $\mathrm{t}_{\mathrm{CP}}=2 \mathrm{~ms}$ ).

Figure 3. Two-dimensional $\left\{{ }^{1} \mathrm{H}\right\}{ }^{31} \mathrm{P}$ HetCor MAS NMR spectra of a mature bone tissue sample originating from a two-year-old sheep (contact time, $\mathrm{t}_{\mathrm{CP}}=1 \mathrm{~ms}$ ), and of the physical mixture of HA and ACP powders (HA/ACP mixture) (contact time, $\mathrm{t}_{\mathrm{CP}}=3 \mathrm{~ms}$ ).

Figure 4. Two-dimensional ${ }^{1} \mathrm{H}$ Double CP EXSY MAS NMR spectra of the biomimetic apatites CHA and CHA-SBF for two different mixing times (i.e., $\mathrm{t}_{\mathrm{mix}}=10 \mu \mathrm{s} \& \mathrm{t}_{\mathrm{mix}}=10 \mathrm{~ms}$ ).

Figure 5. Two-dimensional ${ }^{1} \mathrm{H}$ Double CP EXSY MAS NMR spectra of the physical mixture of HA and ACP powders (HA/ACP mixture) for two different mixing times $\left(\mathrm{t}_{\mathrm{mix}}=10 \mu \mathrm{s} \& \mathrm{t}_{\mathrm{mix}}=\right.$ $10 \mathrm{~ms})$ 
Figure 6. Two-dimensional ${ }^{1} \mathrm{H}$ Double EXSY MAS NMR spectra of a mature bone tissue sample originating from a two-year-old sheep for two different mixing times $\left(t_{\text {mix }}=10 \mu \mathrm{s} \& \mathrm{t}_{\text {mix }}\right.$ $=10 \mathrm{~ms})$. 

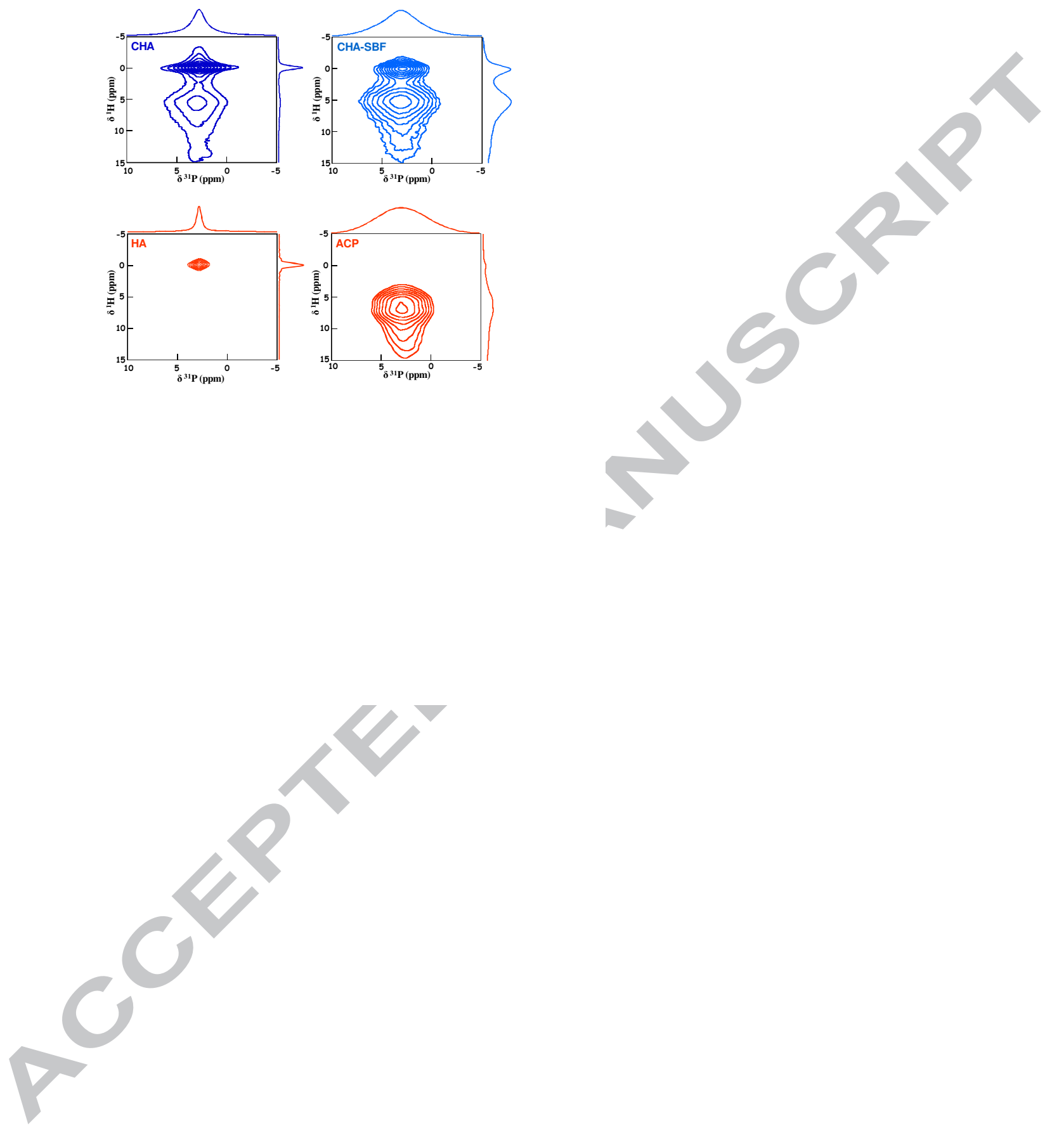

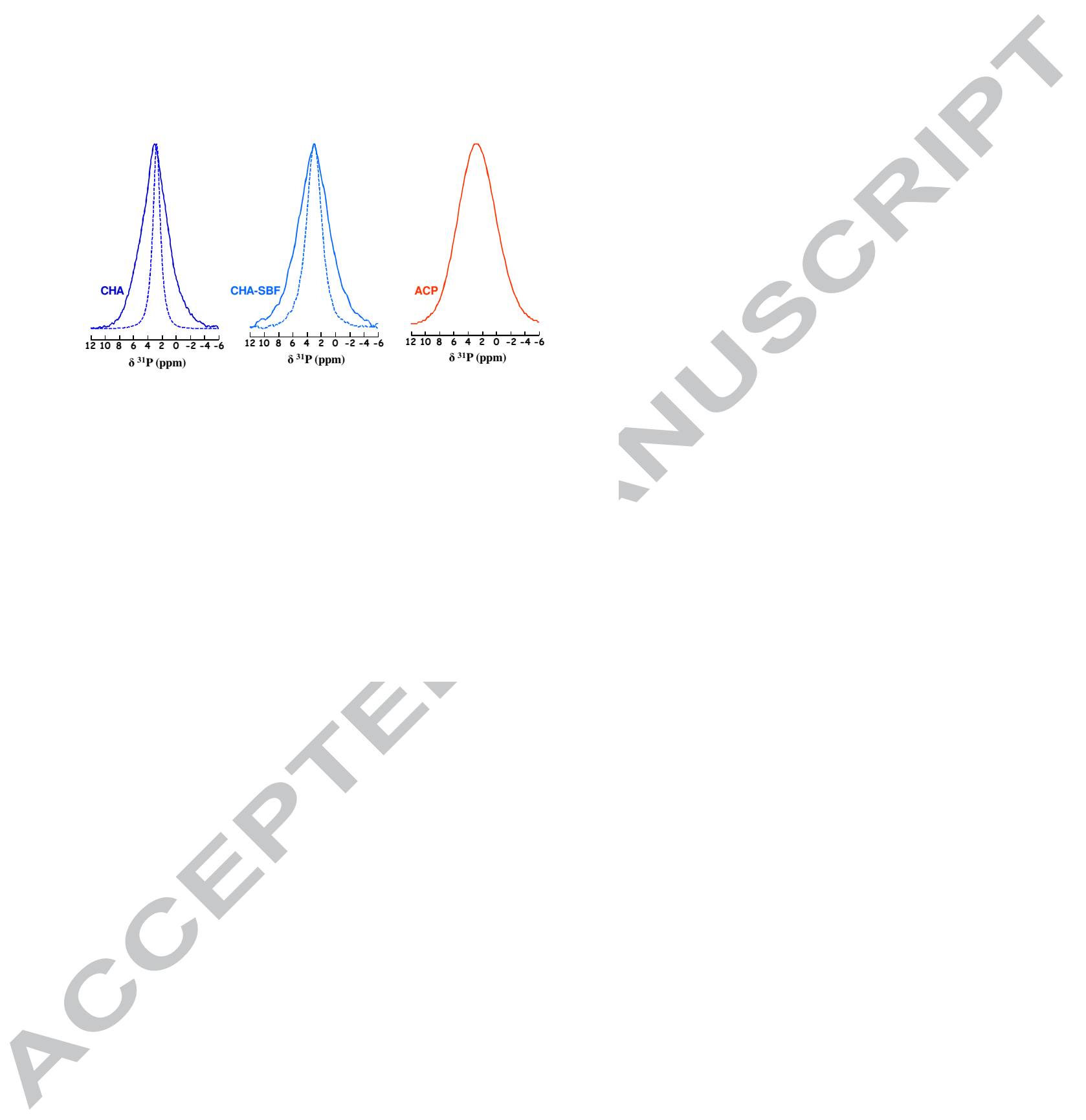

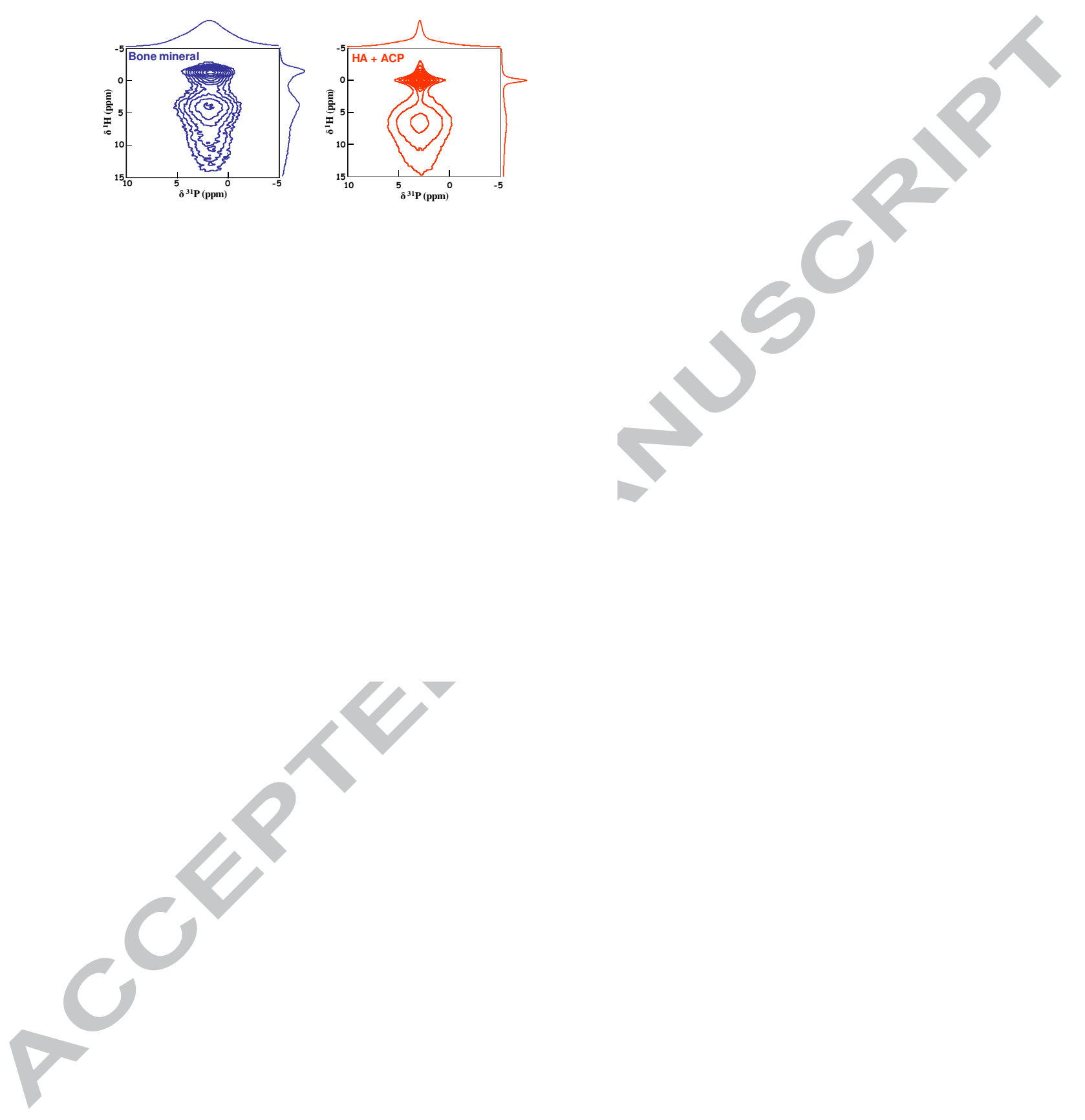

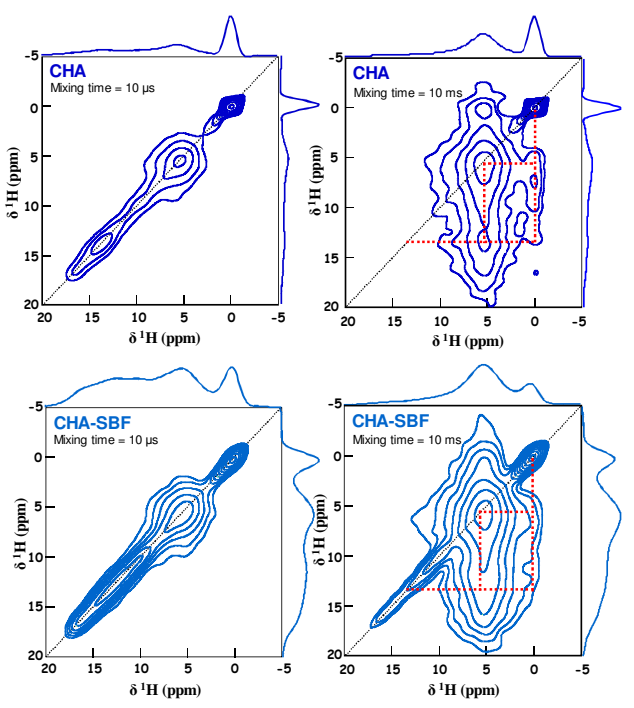

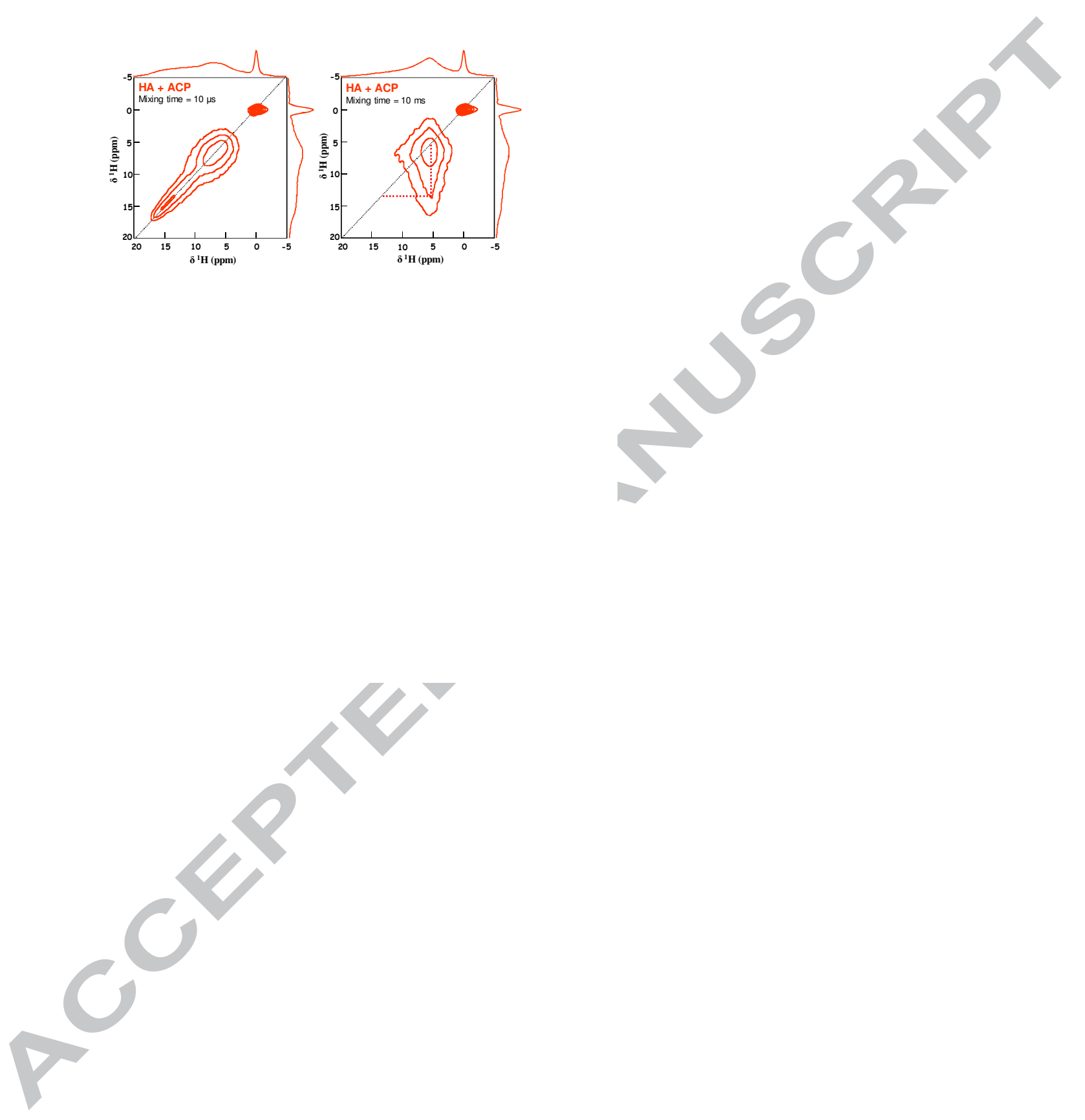

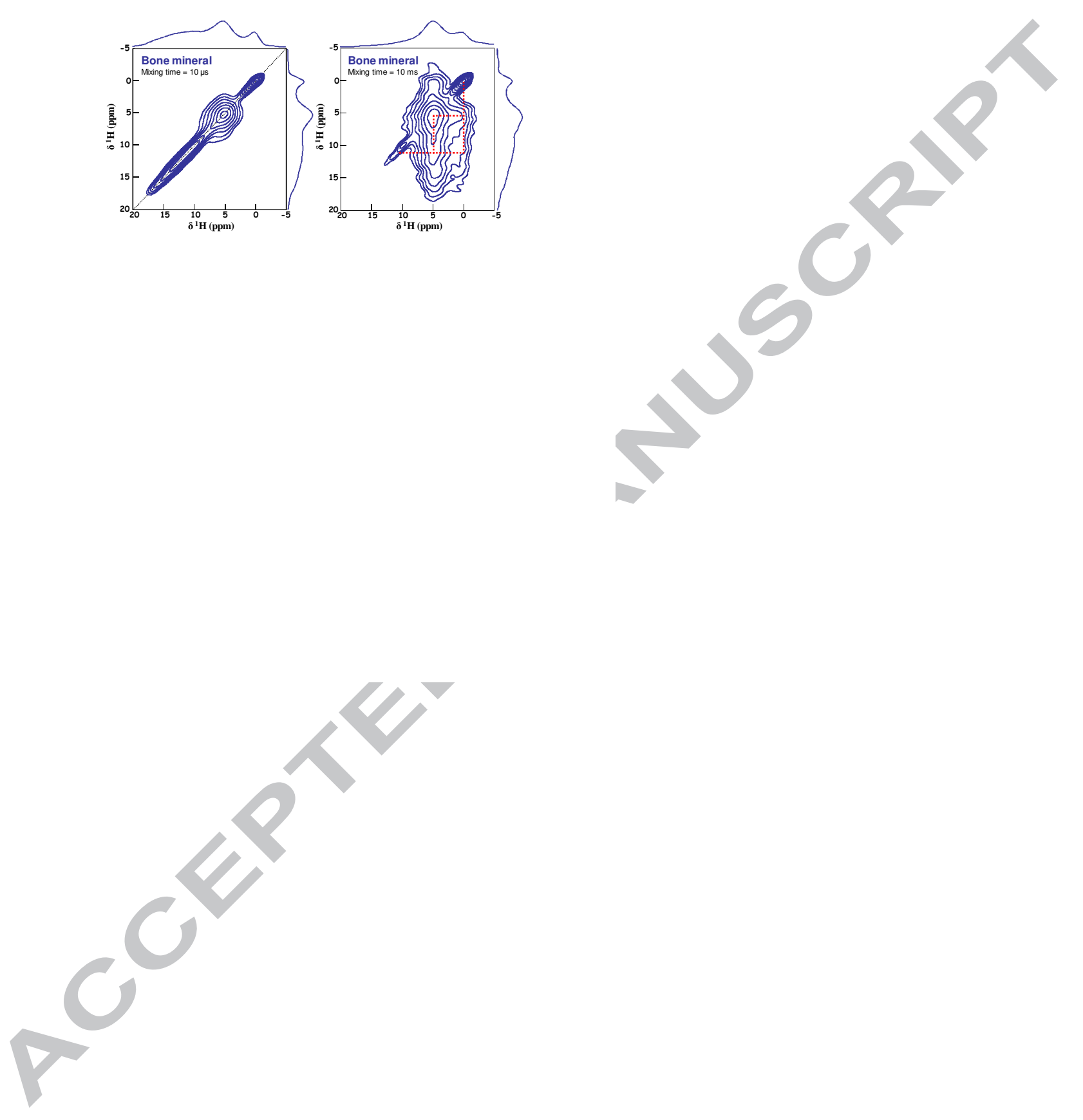
Statement of Significance :

Questions still persist on the structural organization of bone and biomimetic apatites. The existing model proposes a core/shell structure, with an amorphous surface layer coating a crystalline bulk. The accuracy of this model is still debated because amorphous calcium phosphate (ACP) environments could also arise from a transient phase precursor of apatite.

Here, we provide a NMR spectroscopy methodology to reveal the origin of these ACP environments in bone mineral or in biomimetic apatite. The ${ }^{1} \mathrm{H}$ magnetization exchange between protons arising from amorphous and crystalline domains shows unambiguously that an ACP layer coats the apatitic crystalline core of bone et biomimetic apatite platelets. 


\section{BONE MINERAL}

Q $\mathrm{HO} \rightleftharpoons \mathrm{H}_{2} \mathrm{O}$

( $1 \mathrm{HO}$

$\mathrm{HPO}_{4}{ }^{2} \phi$

- $\mathrm{H}_{2} \mathrm{O} \hat{\varphi}$

Amorphous

-5 surface layer

vs

Transient amorphous
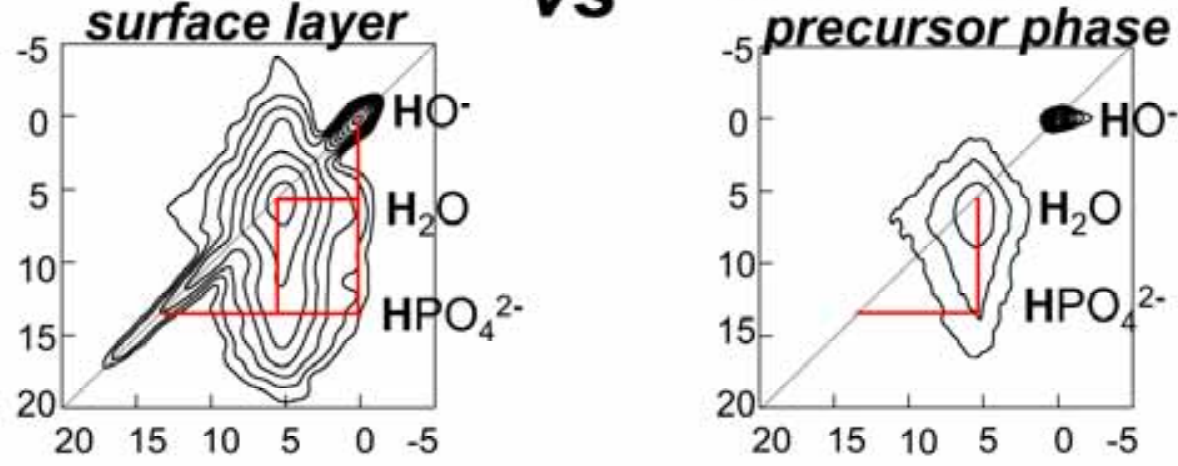